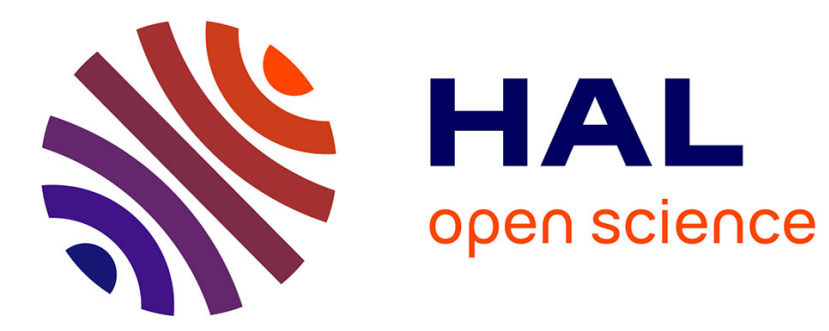

\title{
Phage display-based identification and potential diagnostic application of novel antigens from subsp. small colony type
}

Shamoon Naseem, Jochen Meens, Joerg Jores, Martin Heller, Stefan Dübel, Michael Hust, Gerald-F. Gerlach

\section{To cite this version:}

Shamoon Naseem, Jochen Meens, Joerg Jores, Martin Heller, Stefan Dübel, et al.. Phage displaybased identification and potential diagnostic application of novel antigens from subsp. small colony type. Veterinary Microbiology, 2010, 142 (3-4), pp.285. 10.1016/j.vetmic.2009.09.071 . hal-00587279

\section{HAL Id: hal-00587279 https://hal.science/hal-00587279}

Submitted on 20 Apr 2011

HAL is a multi-disciplinary open access archive for the deposit and dissemination of scientific research documents, whether they are published or not. The documents may come from teaching and research institutions in France or abroad, or from public or private research centers.
L'archive ouverte pluridisciplinaire HAL, est destinée au dépôt et à la diffusion de documents scientifiques de niveau recherche, publiés ou non, émanant des établissements d'enseignement et de recherche français ou étrangers, des laboratoires publics ou privés. 


\section{Accepted Manuscript}

Title: Phage display-based identification and potential diagnostic application of novel antigens from Mycoplasma mycoides subsp. mycoides small colony type

Authors: Shamoon Naseem, Jochen Meens, Joerg Jores,

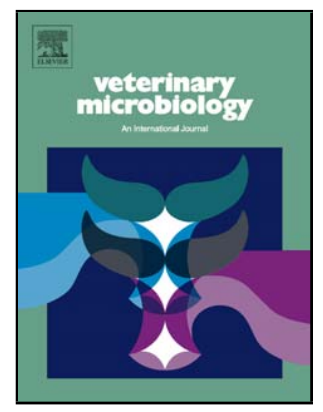
Martin Heller, Stefan Dübel, Michael Hust, Gerald-F. Gerlach

PII: S0378-1135(09)00521-5

DOI: doi:10.1016/j.vetmic.2009.09.071

Reference: VETMIC 4634

To appear in: $\quad$ VETMIC

Received date: 27-6-2009

Revised date: 26-9-2009

Accepted date: $\quad$ 29-9-2009

Please cite this article as: Naseem, S., Meens, J., Jores, J., Heller, M., Dübel, S., Hust, M., Gerlach, G.-F., Phage display-based identification and potential diagnostic application of novel antigens from Mycoplasma mycoides subsp. mycoides small colony type, Veterinary Microbiology (2008), doi:10.1016/j.vetmic.2009.09.071

This is a PDF file of an unedited manuscript that has been accepted for publication. As a service to our customers we are providing this early version of the manuscript. The manuscript will undergo copyediting, typesetting, and review of the resulting proof before it is published in its final form. Please note that during the production process errors may be discovered which could affect the content, and all legal disclaimers that apply to the journal pertain. 
1 Phage display-based identification and potential diagnostic application of

2 novel antigens from Mycoplasma mycoides subsp. mycoides small colony type.

3

4 Shamoon Naseem $^{1)}$, Jochen Meens ${ }^{1)}$, Joerg Jores ${ }^{2)}$, Martin Heller ${ }^{3)}$, Stefan

5 Dübel $^{4)}$, Michael Hust ${ }^{4)}$, and Gerald-F. Gerlach ${ }^{1 \S^{*}}$

6

7 1) Stiftung Tierärztliche Hochschule Hannover, Institut für Mikrobiologie,

8 Zentrum für Infektionsmedizin, Bischofsholer Damm 15, 30173 Hannover,

9 Germany

10 2) International Livestock Research Institute, Old Naivasha Road, P.O.Box

1130709,00100 Nairobi, Kenya

12 3) Friedrich-Loeffler-Institute (FLI) Bundesforschungsinstitut für Tiergesundheit,

13 Naumburger Straße 96a, 07743 Jena.

14 4) Technische Universität Braunschweig, Institut für Biochemie und

15 Biotechnologie, Abteilung Biotechnologie, Spielmannstr.7, 38106

16 Braunschweig, Germany

17

18

§) both senior authors contributed equally

19

$20 *$ corresponding author:

21 Gerald-F. Gerlach

22 Current address: IVD GmbH

23

24

25

26

27

28
Heisterbergallee 12

30453 Hannover

Germany

Phone.: +49-511-22002945

Fax: +49-511-22002999

Email: gfgerlach@gmx.de 


\section{Abstract}

31 Contagious Bovine Pleuropneumonia caused by Mycoplasma mycoides subsp.

32 mycoides small colony type is a respiratory disease of considerable economic

33 importance in sub-Saharan Africa; control of the disease in Africa is hampered by

34 diagnostic tests which are suited for herd-level but not for individual animal

35 diagnostics. In the work presented we identified 22 potential immunogenic

36 antigens of the Kenyan outbreak strain B237 by using phage display technology.

37 We determined the relative strength of immunogenicity, the discriminatory

38 capacity between bovine positive and negative sera, and the cross reactivity with

39 rabbit hyperimmune sera directed against 15 different mycoplasmal species. The

40 three best-performing antigens, a conserved hypothetical protein (MSC_0636), a

41 glycosyl transferase (MSC_0108), and an acyl carrier protein phosphodiesterase

42 (MSC_0029) were considered candidate diagnostic proteins. They were expressed

43 as GST-fusion proteins in E. coli, purified, and used in an ELISA as solid phase

44 antigens. The diagnostic potential of the recombinant antigens was tested using

45 the sera of ten experimentally infected animals and six control animals. This

46 prototype test resulted in $100 \%$ diagnostic sensitivity and specificity. In

47 comparison, the complement fixation test and the competitive ELISA performed

48 with a diagnostic sensitivity of $70 \%$ and $60 \%$, respectively.

49

50 Keywords: Mycoplasma mycoides subsp. mycoides small colony type; phage display; diagnostic antigens 
54 Contagious Bovine Pleuropneumonia (CBPP) is a highly infectious respiratory

55 disease in cattle caused by Mycoplasma mycoides subsp. mycoides small colony 56 type (MmmSC) and solely transmitted by animal to animal contact. The disease is 57 of major economic importance in subsaharan Africa (FAO, 2003) with a constant 58 risk of reintroduction into other parts of the world. Diagnosis is primarily based 59 on serology currently done by complement fixation test (CFT), competitive

60 ELISA (cELISA) (Le Goff and Thiaucourt, 1998) and a lipoprotein Q-based

61 ELISA (Bruderer et al., 2002). Both ELISA tests closely correlate with the CFT

62 reported to have a diagnostic sensitivity of 64 to $70 \%$ and a diagnostic specificity 63 of $98 \%$ (Amanfu et al., 2000; Marobela-Raborokgwe et al., 2003). For a reliable 64 diagnosis of disease on the individual animal level the diagnostic sensitivity needs 65 to be improved without losing specificity. To achieve this goal, novel diagnostic 66 antigens need to be identified.

67 Recently it has been shown that this goal can be achieved effectively using a non-

68 lytic phage display approach based on phage M13 and designated as pHORF-

69 system (Kügler et al., 2008); it improves the panning and screening process

70 compared to the lytic lambda-based phage display system (Beghetto et al., 2009;

71 March et al., 2006; Kügler et al., 2008). Furthermore, the included open reading

72 frame selection and the packaging into "Hyperphage", a helperphage not encoding

73 pIII protein on its genome, improve the subsequent panning process (Hust et al.,

74 2006; Kügler et al., 2008; Soltes et al., 2007; Rondot et al., 2001).

75 In the work presented, the phage M13-based pHORF system was used to identify

76 novel immunogenic epitopes of $\mathrm{MmmSC}$ which are potentially suitable not only

77 for herd-level but also for individual animal diagnostics. 


\section{2. Materials and Methods}

2.1 Bacterial strains, phages, growth conditions, plasmids and sera

82 The strains, plasmids, primers and sera used in this work are listed in Table 1.

83 Escherichia coli strains were cultured in Luria-Bertani medium supplemented

84 with the appropriate antibiotics (ampicillin, $100 \mu \mathrm{g} / \mathrm{l}$, kanamycin, $30 \mu \mathrm{g} / \mathrm{l}$ ). The

$85 \mathrm{MmmSC}$ field isolate B237 was grown as stationary culture for three days in

86 modified PH medium (Kirchhoff and Rosengarten, 1984), supplemented with

$8720 \%$ equine serum (WDT, Garbsen, Germany) at $37{ }^{\circ} \mathrm{C}$ in a $5 \% \mathrm{CO}_{2}$ atmosphere.

88 The 10 bovine anti-MmmSC sera used in this study were derived from

89 experimentally infected cattle (Jores et al., 2008). A positive control serum was

90 obtained by pooling equal volumes of these sera. The six negative sera used were

91 obtained from uninfected cattle from a CBPP free region within Kenya. A

92 negative control serum was generated by pooling equal volumes of these sera. The

93 rabbit sera directed against different mycoplasmal species had been raised

94 previously against the respective whole cell bacterins.

95

96

97

98

99

100 Site-specific mutation of the phagemid vector pHORF3 (Kügler et al., 2008) was

101 performed using primers oMHLacZPro_f, oMHORF3_pme_rX1 and

102

103 oMHORF3_pme_rXX2 (Table 1) such that the unique PmeI site used for insertion of foreign DNA is shifted by 1 and 2 bp resulting in plasmids pHORF3X and 
104 pHORF3XX, respectively (Fig. 1). Genomic DNA of the MmmSC African field

105 strain B237 was isolated as described previously (Meens et al., 2006) and digested

106 using five different blunt end-cutting restriction endonucleases (AluI, PsiI, SspI,

107 HpyCH4V, RsaI). DNA fragments with a size of 100-1000 bp were isolated after

108 separation in an agarose gel using the Qiagen PCR DNA and gel band purification

109 kit (Qiagen, Hilden, Germany) according to the manufacturer's instructions, and

110 ligated into PmeI-restricted vectors pHORF3, pHORF3X and pHORF3XX (Fig.

111 1). The genomic $M m m S C$ phage library was constructed as described previously

112 (Kügler et al., 2008).

113

1152.3 Selection of phage encoding immunogenic oligopeptides of MmmSC and

116 production of individual phage clones for screening

118 The panning of phage presenting immunogenic peptides on the surface was

119 performed using the bovine positive control serum pre-absorbed to Hyperphage in

120 order to prevent unspecific reactivity with antibodies directed against phage-

121 surface epitopes. The preabsorbed serum was coupled to MaxiSorb ${ }^{\circledR} 96$ well

122 microtitre plates (Nunc, Wiesbaden, Germany) via rabbit anti-bovine IgG (Sigma,

123 Deisenhofen, Germany), and four successive panning rounds were performed as

124 previously described (Kügler et al., 2008). Individual clones were picked from the

125 titration plates of the last panning round.

126 For production of individual phage clones, polypropylene 96-well U-bottom

127 plates (Greiner bio-one, Frickenhausen, Germany) containing $175 \mu 1$ of 2 x TY-

128 GA medium (1 \% Bacto-Yeast Extract, $1.6 \%$ Bacto Tryptone, $0.05 \%$ NaCl; 100

$129 \mathrm{mM}$ glucose, $100 \mu \mathrm{g} / \mathrm{ml}$ ampicillin) per well were inoculated with single clones 
130 and incubated at $37{ }^{\circ} \mathrm{C}$ with constant shaking at $250 \mathrm{rpm}$ overnight. Cultures were

131 expanded to $1.5 \mathrm{ml}$ of $2 \times$ TY-GA medium, infected with $5 \times 10^{9}$ cfu Hyperphage

132 per tube and incubated at $37{ }^{\circ} \mathrm{C}$ without shaking for $30 \mathrm{~min}$, followed by $30 \mathrm{~min}$

133 incubation with shaking at $250 \mathrm{rpm}$. Cells were centrifuged at 3,220 $\mathrm{xg}$ for

$13410 \mathrm{~min}$ and the supernatants were discarded. The bacterial pellets were

135 resuspended in $1.5 \mathrm{ml}$ of $2 \times \mathrm{TY}$ medium containing ampicillin $(100 \mu \mathrm{g} / \mathrm{ml})$ and

136 kanamycin $(30 \mu \mathrm{g} / \mathrm{ml})$ and incubated at $30{ }^{\circ} \mathrm{C}$ at $250 \mathrm{rpm}$ overnight for phage

137 production.

138 In order to confirm the antigenicity of individual phage clones PolySorb ${ }^{\circledR} 96$ well

139 microtitre plates (Nunc) were coated overnight with $10 \mu \mathrm{l}\left(1 \times 10^{10} \mathrm{pfu} / \mathrm{ml}\right)$ of

140 individual phage in $100 \mu \mathrm{l}$ of carbonate buffer $(100 \mathrm{mM} \mathrm{NaHCO} 3,46 \mathrm{mM}$

$141 \mathrm{Na}_{2} \mathrm{CO}_{3}, \mathrm{pH}$ 9.6). The ELISA was developed using the positive control serum

142 (diluted 1:100), goat anti-bovine IgG conjugated with horseradish peroxidase

143 (HRP; Jackson ImmunoResearch Laboratories, Dianova, Hamburg, Germany) as a

144 conjugate and 2,2-azino-di-[3-ethylbenzithiazoline sulfonate] (ABTS; Roche

145 Diagnostics, Mannheim, Germany) as a substrate. The staining reaction was

146 stopped by adding $100 \mu \mathrm{l}$ of $50 \%(\mathrm{v} / \mathrm{v})$ methanol. The absorbance at $405 \mathrm{~nm}$ and

147 scattered light at $492 \mathrm{~nm}$ were measured using a Sunrise ${ }^{\circledR}$ microtiter plate reader

148 (Tecan, Crailsheim, Germany).

1512.4 Sodium dodecyl sulfate-polyacrylamide gel electrophoresis (SDS-PAGE) and

\section{Western blot}

154 SDS-PAGE was performed following standard procedures using a Protean II 
155 Minigel system (BioRad Inc, Munich, Germany). Western blotting of the SDS-

156 PAGE minigels was done using the Mini Trans-Blot ${ }^{\circledR}$ system (BioRad). The

157 bovine positive and negative control serum and a rabbit anti-GST serum were

158 used as primary antibodies; blots were developed using alkaline phosphatase-

159 conjugated goat anti-bovine or goat anti-rabbit IgG antibody (Jackson

160 ImmunoResearch Laboratories) and BCIP (5-bromo-4-chloro-3-indolyl

161 phosphate) and NBT (nitroblue tetrazolium) as substrate.

162

2.5 Preparation of recombinant fusion proteins and ELISA set-up

165

166 The MmmSC genes encoding immunogenic epitopes as assessed by ELISA of

167 individual phage clones were identified by database analysis. The respective parts

168 of the genes located between two TGA codons were amplified by PCR using

169 primer pairs with an EcoRI- (upstream primer) or NotI-restriction endonuclease

170 site (downstream primer) at their 5'ends (Table 1). The corresponding PCR

171 fragments were digested with EcoRI and NotI and ligated into pGEX-5x-2,

172 resulting in plasmids pMSC0029-500, pMSC0108-500 and pMSC0636-500.

173 Recombinant fusion proteins were prepared as inclusion bodies as described

174 previously (Gerlach et al., 1992) and dissolved in guanidine hydrochloride (4 M).

175 To remove small-sized contaminating material, the solution was washed twice in

176 guanidine hydrochloride (4M) using a $10 \mathrm{kDa}$ cut-off (MicroCentricon 10 system,

177 Amicon, Beverly, Mass., U.S.A.). Using BSA as reference the concentration of the

178 purified protein (desalted by precipitation with trichloroacetic acid [TCA]) was

179 then determined by SDS PAGE and staining with Coomassie blue. The structure 
180

181

182

183

184

185

186

188

189

190

191 in order to remove antibodies directed against contaminating $E$. coli components

192 in the semi-purified antigen preparation.

195 3. Results

196

197

\subsection{Identification of immunogenic peptides}

199 After performing four panning rounds with the positive control serum a total of

200147 clones (49 from each of the three libraries based on vectors with the cloning

201 site in three different reading frames with respect to the 3' $\mathrm{pIII}$ protein-encoding

202 ORF) were sequenced. One hundred and thirty four clones contained analyzable

203 sequence and showed an ORF consisting of a MmmSC-derived genomic DNA

204 fragment in frame with both the pelB signal sequence and the PIII protein-

205 encoding ORF. Upon NCBI Blast analysis (http://www.ncbi.nlm.nih.gov/blast/ 
206 Blast.cgi) 22 different clones were identified with each clone present at least twice

207 in the random selection of sequenced clones (Table 2).

\subsection{Selection of clones with diagnostic potential}

212 The individual clones were amplified and the relative strength of serum reactivity

213 was determined by phage ELISA. Eight clones showing a reactivity of more than

$21430 \mathrm{OD} \%$ with respect to $\mathrm{MmmSC}$ whole cell lysate (Table 2) were considered to

215 be of potential diagnostic value and were subjected to further investigation. The

216 clones were individually amplified, and the discrimination between positive and

217 negative control serum was investigated by ELISA. For six of the eight clones

218 (MSC_0029, 0108, 0636, 0656, 1009 and 1062) at least a 3-fold difference in titre

219 was observed between the positive and the negative control serum (data not

220 shown). These six clones were tested with respect to their discriminatory potential

221 using the ten individual positive sera and the six individual negative sera

222 contained in the respective control sera. Four of the clones (MSC_029, 108, 636

223 and 1062) reacted with all individual positive sera; no overlap in OD\%-values was

224 seen between positive and negative sera (data not shown).

225 These four clones were investigated for cross reactivity to other mycoplasmal

226 species using rabbit hyperimmune sera previously raised against 15 different

227 mycoplasmal species. All four clones (MSC_0029, MSC_0108, MSC_0636, and

228 MSC_1062) were highly positive with the hyperimmune serum directed against

229 MmmSC. Two clones showed clear cross-reactivity (i.e. more than 1.5-fold of the

230 average reactivity with the negative control serum) with the serum directed

231 against $M$. capricolum subsp. capricolum; for clone MSC_1062 an additional 
cross-reactivity against A. modicum and M. bovis was observed (Table 3) and,

233 therefore, this clone was excluded from further analyses. The three remaining

234 clones (MSC_0029, MSC_0108 and MSC_0636) were expressed as GST fusion

235 proteins.

\subsection{Potential of recombinant GST-fusion proteins as diagnostic antigens}

240 All fusion proteins had a molecular mass corresponding to the calculated masses

241 of $32.5,32.0$, and $45.0 \mathrm{kDa}$, respectively. Approximately $90 \%$ of the fusion

242 protein preparations consisted of recombinant antigen (Fig. 2A). The proteins

243 reacted strongly positive with both the anti-GST and the positive control serum

244 but did not show any reaction with the negative control serum (Fig. 2B-D).

245 The purified fusion proteins, upon checkerboard titration performed to determine

246 the suitable coating concentration of $2.5 \mu \mathrm{g} / \mathrm{ml}$, were used as solid-phase antigens.

247 In a first ELISA, using rabbit hyperimmune sera previously raised against

$248 \mathrm{MmmSC}$, a 32-times higher titre of the positive versus the negative serum was

249 observed (data not shown) thereby showing suitability of the antigens in principal.

250 In a second ELISA, serial two-fold dilutions of the bovine positive and negative

251 control sera were used after absorption against a lysate of $E$. coli pGEX-5x-2

252 transformants. The slope of the regression curve of the log-log transformed data

253 obtained with the positive control serum was determined to be 0.72 thereby

254 confirming the suitability of the coating concentration; in addition, an at least

255 three-fold difference in titre and a 2.5 -fold difference of OD\%-values was

256 observed between positive and negative control serum thus confirming the

257 discriminatory power of the antigens. 
258 Using these antigens and coating concentrations the ELISA was performed three

259 times in duplicate for 1:500 dilutions of the individual positive and negative sera.

260 The intra-assay variation for all three ELISAs was determined to be below

2615 OD $\%$ and the inter-assay variation below 20 OD $\%$. Applying a cut-off range of

26250 OD \% all three ELISAs resulted in an analytical sensitivity and specificity of

$263100 \%$ as compared to a $70 \%$ sensitivity for the complement fixation test and

$26460 \%$ for the competitive ELISA commercially available (Fig. 3).

\section{4. Discussion}

269 The control of the continuous spread of CBPP in sub-Saharan Africa is severely

270 limited by the lack of sufficiently sensitive and specific diagnostic tests. In an

271 attempt to improve the diagnostic possibilities we set out to identify novel

272 MmmSC-derived antigens using a non-lytic M13-based phage display system

273 (Kügler et al., 2008). The construction of phage display libraries in three different

274 reading frames using five different restriction endonucleases with a 4 mer

275 recognition sequence was considered to result in a reasonable coverage of the

276 MmmSC genome although the three vectors facilitate the generation of a

277 functional $\mathrm{pIII}$ fusion protein only for one of the three possible reading frames

278 (Fig. 1). Thus, in silico analysis of the MmmSC PG1 genome revealed that the 279 restriction enzyme digests resulted in a total of 9,178 restriction endonuclease 280 fragments of 100 to $1000 \mathrm{bp}$ in length. In total these fragments cover 3,413,598 bp

281 which corresponds to 2.8 times the $\mathrm{MmmSC}$ genome size. The finding that each

282 peptide was present at least twice in the pool of 147 clones analyzed implied that

283 the number of panning rounds was sufficient to eliminate non-specific binders 
284 (Eshaghi et al., 2005; Kügler et al., 2008). When comparing the open reading

285 frames (ORFs) identified with the results of a previous study by March et al.

286 (March et al., 2006) only ORF MSC_0266 encoding a pyruvate dehydrogenase

287 was identified in both studies. This is likely due to the different methodologies

288 used; thus, March et al. (March et al., 2006) used a lytic bacteriophage Lambda

289 ZAP Express vector with insert sizes of 6 to $8 \mathrm{~kb}$ and screened using rabbit $\operatorname{IgG}$

290 antibodies.

291 Some of the initially identified antigens are intracellular proteins. This is in

292 accordance with many other studies, where intracellur proteins were found to be

293 immunogenic (Kügler et al., 2008; March et al., 2006; Delvecchio et al., 2006;

294 Cho et al., 2008; Kodzius et al., 2003). A possible explanation for this

295 phenomenon could be the release of intracelluar proteins by cell lysis or by

296 programmed cell death (Lewis, 2000).

297 Four of 22 identified antigens were consistently recognized by all positive sera

298 and showed sufficient discrimination of all negative sera. Using rabbit

299 hyperimmune sera directed against 15 other bovine mycoplasmal species these

300 four antigens were tested for serological cross-reactivity which might limit

301 diagnostic specificity. The cross-reactivity of all four antigens with $M$. capricolum

302 subsp. capricolum appeared acceptable since sequence analysis of the 16S rRNA

303 (Pettersson et al., 1994, 1996) and of five conserved protein-coding sequences

304 (Manso-Silván et al., 2007) showed a high sequence similarity and, consequently,

305 a close phylogenetic relationship between MmmSC, M. mycoides subsp. capri

306 and M. capricolum subsp. capricolum, and the other members of the "mycoides-

307 cluster". In addition, it has been reported that M. capricolum subsp. capricolum

308 can cause CBPP-like disease in cattle (Ajuwape et al., 2003). Acholeplasma

309 modicum and M. bovis, however, are not members of the "mycoides-cluster"; 
310 since serological cross-reactivity particularly with the frequently occurring bovine

311 pathogen $M$. bovis is unacceptable for a diagnostic test, ORF MSC_1062 was

312 excluded from further analyses. Immunoblot analysis of the three remaining

313 antigen-GST fusion proteins showed a strong reaction particularly of antigens

314 MSC_0108 and MSC_0636 (Fig. 2) thereby confirming the initial panning results

315 where these two peptides had elicited the highest reactivity.

316 The testing of the cohort sera (16 infected and six non-infected) resulted in a

317 diagnostic sensitivity and specificity of $100 \%$ each in comparison to a diagnostic

318 sensitivity of $70 \%$ for the CFT and $60 \%$ for the cELISA (Fig. 3). This result

319 implies that all three antigens are potentially suitable to improve the reliability of

320 current serological testing which is primarily hampered by low diagnostic

321 sensitivity (Marobela-Raborokgwe et al., 2003). However, the cohort sera used

322 were by no means representative; in addition, $M m m S C$ is known to show a high

323 antigenic variability (Gonçalves et al., 1998; Persson et al., 2002) and different

324 breeds of cattle may show a distinct serological response to MmmSC infection.

325 Therefore, in order to support the potential suitability of these antigens for field

326 application, additional sera from experimentally infected cattle as well as field

327 sera from different geographical regions need to be investigated in the future. 
331 SN was funded by Higher Education Commission (HEC) Pakistan and German

332 Academic Exchange Service (DAAD), Germany.

\section{References}

Ajuwape, A., Adetosoye, A., Ikheloa, J., Alaka, O., Taiwo, V., Talabi, O., Otesile, capricolum for cattle immunosuppressed with. Israel. J. Vet. Med. 59, 7374.

Amanfu, W., Sediadie, S., Masupu, K. V., Raborokgwe, M. V., Benkirane, A., Geiger, R., Thiaucourt, F., 2000. Comparison between c-ELISA and CFT in detecting antibodies to Mycoplasma mycoides mycoides biotype SC in cattle affected by CBPP in Botswana. Ann. N. Y. Acad. Sci. 916, 364-369.

Beghetto, E., De Paolis, F., Montagnani, F., Cellesi, C., Gargano, N., 2009.

Bruderer, U., Regalla, J., Abdo, E., Huebschle, O. J. B., Frey, J., 2002. Discovery of new Mycoplasma pneumoniae antigens by use of a wholegenome lambda display library. Microbes Infect. 11, 66-73.

352 Cho, Y. S., Lee, H. S., Kim, J. M., Lee, M. H., Yoo, H. S., Park, Y. H., Ryu, P. D., 2008. Immunogenic proteins in the cell envelope and cytoplasm of vancomycin-resistant enterococci. J. Immunoassay Immunochem. 29, 319- 
356 Delvecchio, V. G., Connolly, J. P., Alefantis, T. G., Walz, A., Quan, M. A., Patra, G., Ashton, J. M., Whittington, J. T., Chafin, R. D., Liang, X., et al., 2006. Proteomic profiling and identification of immunodominant spore antigens of Bacillus anthracis, Bacillus cereus, and Bacillus thuringiensis. Appl. Environ. Microbiol. 72, 6355-63.

Eshaghi, M., Tan, W. S., Yusoff, K., 2005. Identification of epitopes in the nucleocapsid protein of Nipah virus using a linear phage-displayed random peptide library. J. Med. Virol. 75, 147-52.

FAO 2003. Contagious bovine pleuropneumonia. EMPRES Transbound. Animal

366 Gerlach, G. F., Anderson, C., Potter, A. A., Klashinsky, S., Willson, P. J., 1992. Cloning and expression of a transferrin-binding protein from Actinobacillus pleuropneumoniae. Infect. Immun. 60, 892-898.

369 Gonçalves, R., Regalla, J., Nicolet, J., Frey, J., Nicholas, R., Bashiruddin, J., de Mycoplasma mycoides subsp. mycoides SC isolates: discrimination of major surface proteins. Vet. Microbiol. 63, 13-28.

Hust, M., Meysing, M., Schirrmann, T., Selke, M., Meens, J., Gerlach, G., Dübel, S., 2006. Enrichment of open reading frames presented on bacteriophage M13 using hyperphage. Biotechniques 41, 335-42.

Jores, J., Nkando, I., Sterner-Kock, A., Haider, W., Poole, J., Unger, H., Muriuki, 378 interferon-gamma responses from peripheral blood mononuclear cells of cattle infected with Mycoplasma mycoides ssp. mycoides small colony type. Vet. Immunol. Immunopathol. 124, 192-197. 
381 Kirchhoff, H., Rosengarten, R., 1984. Isolation of a motile mycoplasma from fish. J. Gen. Microbiol. 130, 2439-2445.

383 Kodzius, R., Rhyner, C., Konthur, Z., Buczek, D., Lehrach, H., Walter, G., Crameri, R., 2003. Rapid identification of allergen-encoding cDNA clones by phage display and high-density arrays. Comb. Chem. High Throughput Screen. 6, 147-54.

Kügler, J., Nieswandt, S., Gerlach, G. F., Meens, J., Schirrmann, T., Hust, M., 2008. Identification of immunogenic polypeptides from a Mycoplasma hyopneumoniae genome library by phage display. Appl. Microbiol. Biotechnol. 80, 447-58.

Le Goff, C., Thiaucourt, F., 1998. A competitive ELISA for the specific diagnosis of contagious bovine pleuropneumonia (CBPP). Vet. Microbiol. 60, 179191.

394 Lewis, K., 2000. Programmed cell death in bacteria. Microbiol. Mol. Biol. Rev. $64,503-514$

Manso-Silván, L., Perrier, X., Thiaucourt, F., 2007. Phylogeny of the Mycoplasma mycoides cluster based on analysis of five conserved protein-coding sequences and possible implications for the taxonomy of the group. Int. J.

400 March, J. B., Jepson, C. D., Clark, J. R., Totsika, M., Calcutt, M. J., 2006. Phage library screening for the rapid identification and in vivo testing of

404 Marobela-Raborokgwe, C., Nicholas, R., Ayling, R., Bashiruddin, J. B., 2003. Comparison of complement fixation test, immunoblotting, indirect ELISA, and competitive ELISA for detecting antibodies to Mycoplasma mycoides 

subspecies mycoides small colony (SC) in naturally infected cattle from the 1995 outbreak in Botswana. Onderstepoort J. Vet. Res. 70, 21-27.

409 Meens, J., Selke, M., Gerlach, G..-F., 2006. Identification and immunological characterization of conserved Mycoplasma hyopneumoniae lipoproteins Mhp378 and Mhp651. Vet Microbiol. 116, 85-95.

412 Persson, A., Jacobsson, K., Frykberg, L., Johansson, K., Poumarat, F., 2002. Variable surface protein Vmm of Mycoplasma mycoides subsp. mycoides small colony type. J. Bacteriol. 184, 3712-3722.

415 Pettersson, B., Johansson, K. E., Uhlén, M., 1994. Sequence analysis of 16S rRNA from mycoplasmas by direct solid-phase DNA sequencing. Appl.

418 Pettersson, B., Leitner, T., Ronaghi, M., Bölske, G., Uhlen, M., Johansson, K. E., 1996. Phylogeny of the Mycoplasma mycoides cluster as determined by sequence analysis of the 16S rRNA genes from the two rRNA operons. J. Bacteriol. 178, 4131-4142.

422 Rondot, S., Koch, J., Breitling, F., Dübel, S., 2001. A helper phage to improve single-chain antibody presentation in phage display. Nat. Biotechnol. 19,

425 Soltes, G., Hust, M., Ng, K. K. Y., Bansal, A., Field, J., Stewart, D. I. H., Dübel, S., Cha, S., Wiersma, E. J., 2007. On the influence of vector design on antibody phage display. J. Biotechnol. 127, 626-637. 
428 Figure captions:

429

430 Fig. 1. Cloning vector pHORF3 and derivatives. (A) Schematic of the phage

431 display vector pHORF3. Abbreviations: Lac Pr.: promoter of the bacterial lac

432 operon; RBS: ribosome binding site; pelB: sequence encoding the signal peptide

433 of bacterial pectate lyase, mediating protein secretion into the periplasmic space;

434 ochre: ochre stop codon; amber: amber stop codon; tag: hexahistidine and c-myc

435 tags; terminator: sequence terminating transcription; bla: $\beta$-lactamase gene for

436 ampicillin resistence; ColE1: bacterial origin of DNA replication; M13 ori:

437 intergenic region of phage f1. (B) Comparision of the PmeI cloning site of

438 pHORF3, pHORF3X and pHORF3XX.

440 Fig. 2. Characterisation of GST fusion proteins. (A) SDS PAGE showing

441 aggregate preparations of recombinant fusion proteins of $E$. coli transformants

442 containing pMSC0029-500, pMSC0108-500, pMSC0636-500 and the cloning

443 vector pGEX-5x-2 (Lines 1 to 4). (B) Western blot using anti-GST antibody

444 (1:2000), (C) Western blot using the positive control serum obtained from CBPP-

445 infected animals (1:100) and (D) Western blot using the negative control serum

446 (1:100). All three clones pMSC0029-500, pMSC0108-500, pMSC0636-500 were

447 found to strongly react with the positive control serum and not with the negative

448 control serum. In addition, GST showed only minor reactivity with the positive

449 control serum. 
451 Fig. 3. ELISA results using GST fusion proteins. Sera of ten individual CBPP-

452 infected and six uninfected animals were used in the commercial cELISA and in

453 ELISAs with the GST-fusion proteins as solid phase antigens. The horizontal line

454 indicates the cut-off given for the cELISA.. Solid symbols indicate a deviating

455 outcome of CFT test and ELISA for the respective sera. The OD\%-values give the 456 arithmetic mean of three independent experiments. 
A

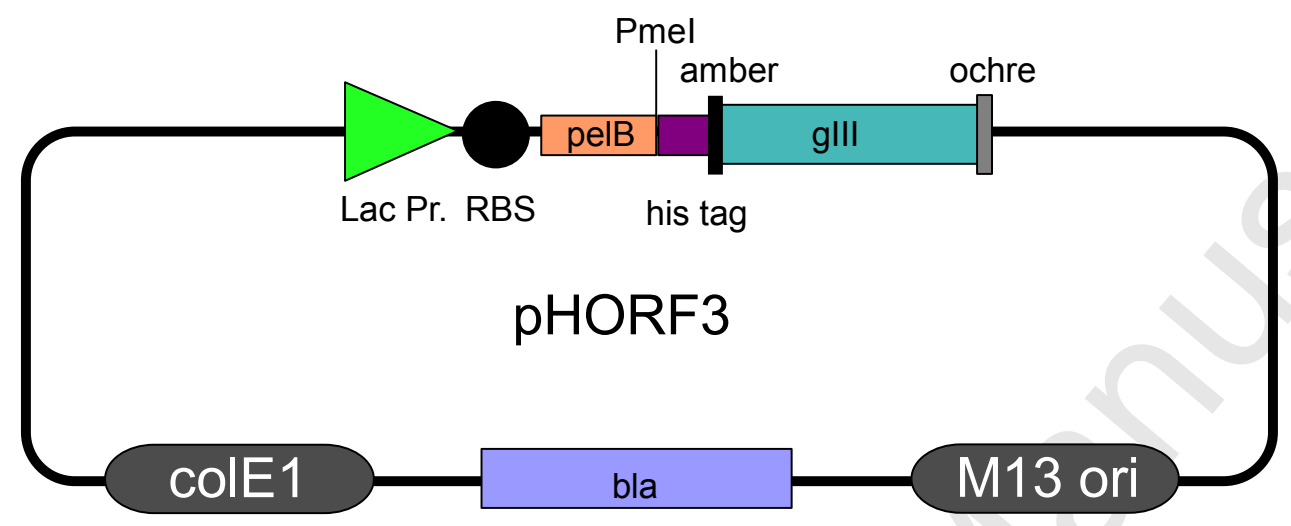

B

pHORF3:

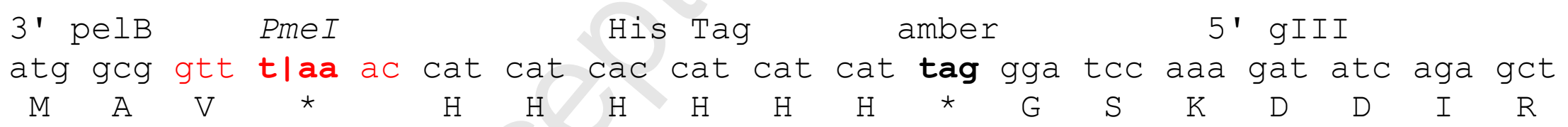

pHORF3X:

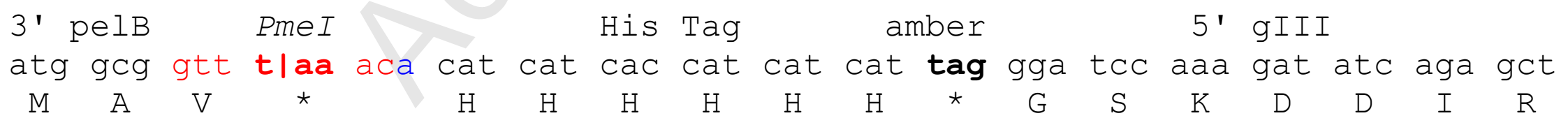

pHORF3XX:
3' pelB
PmeI
His Tag
amber
5' gIII
atg gcg gtt
tlaa aca
$\begin{array}{cccc}\text { a cat cat cac cat } \\ \mathrm{H} & \mathrm{H} & \mathrm{H} & \mathrm{H}\end{array}$
at cat cat

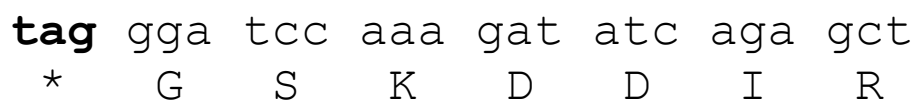




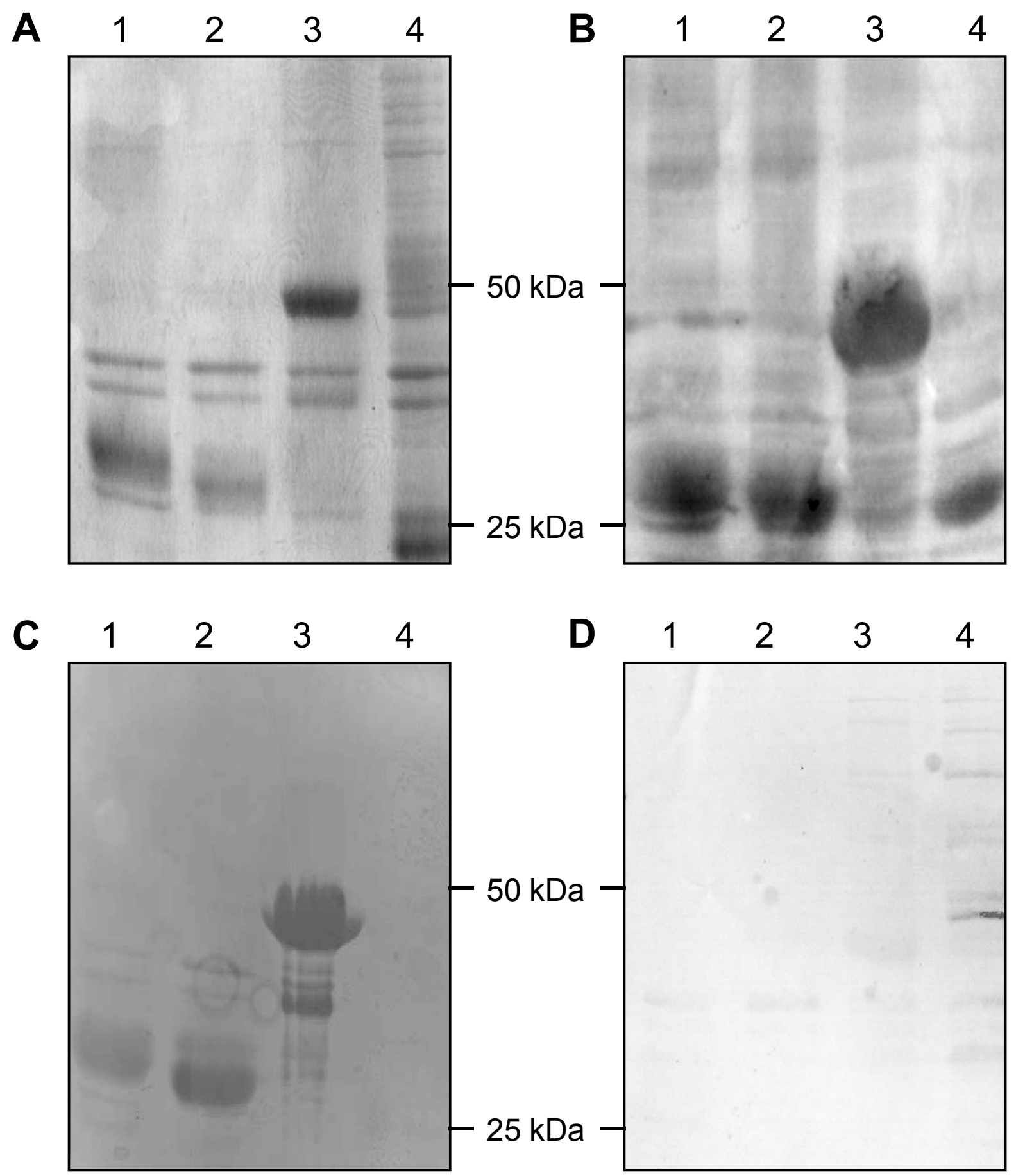

Fig. 2: Characterization of the GST fusion proteins. 


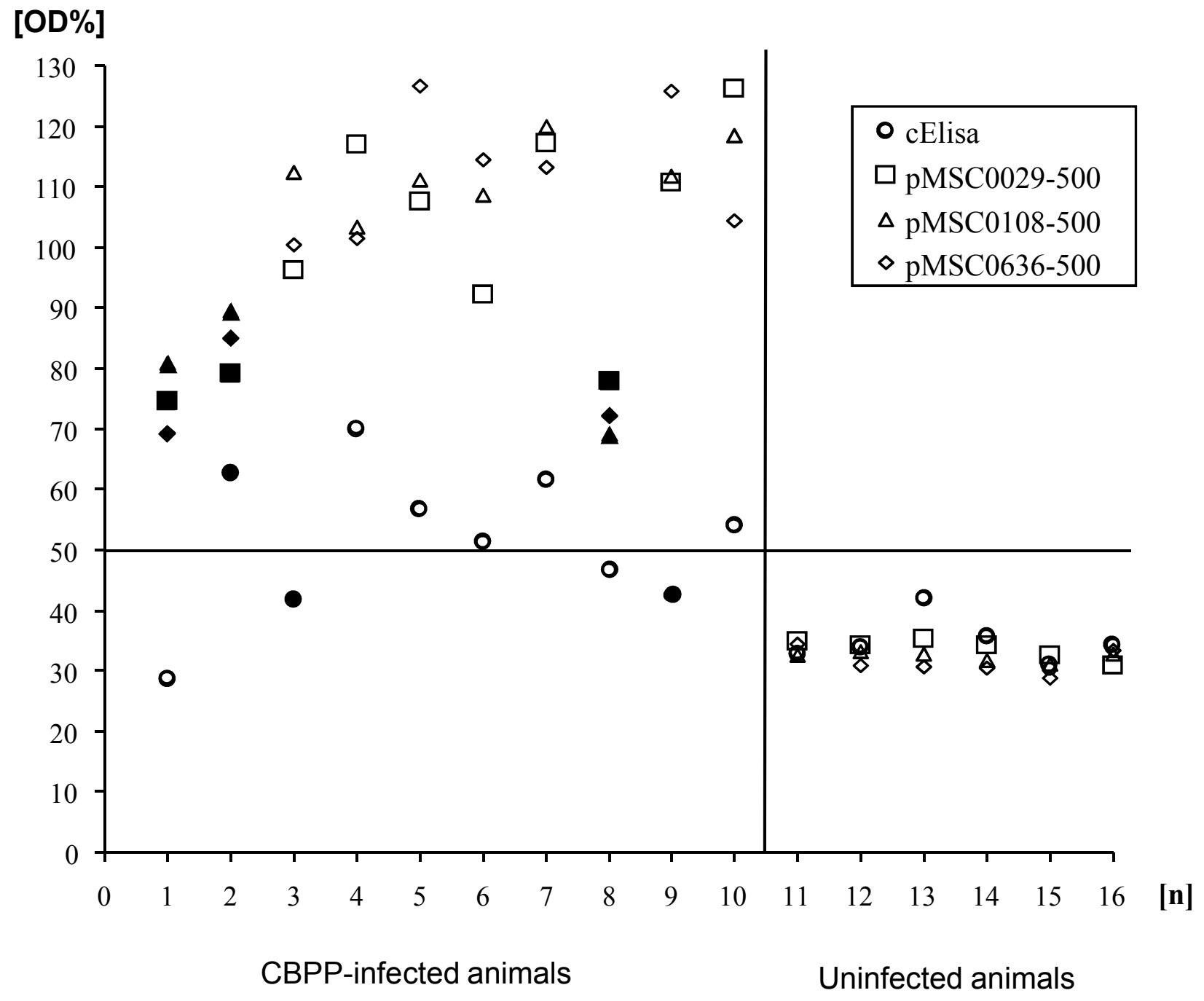

Fig. 3: ELISA results using GST fusion proteins. 


\section{Table 1}

Bacterial strains, plasmids, primers and sera used in this work

\begin{tabular}{|c|c|c|}
\hline $\begin{array}{l}\text { Strains, plasmids, } \\
\text { primers or sera }\end{array}$ & Characteristic(s) & Source or Reference \\
\hline \multicolumn{3}{|l|}{ Strains } \\
\hline$M m m \mathrm{SC}$ & $\begin{array}{l}\text { MmmSC B237, isolated from an outbreak in } \\
\text { Thika/Kenya in } 1997\end{array}$ & Jores et al., 2008 \\
\hline E. coli $\mathrm{EC}-\mathrm{TS} 40.6$ & K12 strain & AG Dübel \\
\hline E. coli $\mathrm{DH} 5 \alpha \mathrm{F}^{\prime}$ & $\begin{array}{l}\mathrm{F}^{\prime} \text { endA1 hsdR17 }\left(\mathrm{r}_{\mathrm{K}}^{-} \mathrm{m}_{\mathrm{K}}{ }^{-}\right) \text {supE44 thi-1 recA1 } \\
\text { gyrA }\left(\mathrm{NaI}^{\mathrm{r}}\right) \text { relA1 } \Delta(\text { lacZYA-argF }) \text { U169 deoR } \\
{[\Phi 80 \mathrm{~d} \text { lac }(\text { lacZ }) \mathrm{M} 15]}\end{array}$ & $\begin{array}{l}\text { New England } \\
\text { Biolabs, Frankfurt, } \\
\text { Germany }\end{array}$ \\
\hline M13K07 & $\begin{array}{l}\text { Helperphage carrying a kanamycin resistance } \\
\text { determinant }\end{array}$ & $\begin{array}{l}\text { Stratagene, } \\
\text { Amsterdam, The } \\
\text { Netherland }\end{array}$ \\
\hline "Hyperphage" & $\begin{array}{l}\text { Helperphage carrying a kanamycin resistance } \\
\text { determinant and truncated gIII }\end{array}$ & Rondot et al., 2001 \\
\hline \multicolumn{3}{|l|}{ Plasmids } \\
\hline pHORF3 & pHORF3 used for insertion of foreign DNA & Kügler et al., 2008 \\
\hline pHORF3X & $\begin{array}{l}\text { pHORF3 was modified such that the singular } \\
\text { PmeI site used for insertion of foreign DNA is } \\
\text { shifted by } 1 \mathrm{bp} \text {, allowing the in-frame fusion with } \\
\text { gIII in an additional reading frame }\end{array}$ & This work \\
\hline pHORF3XX & $\begin{array}{l}\text { pHORF3 was modified such that the singular } \\
\text { PmeI site used for insertion of foreign DNA is } \\
\text { shifted by } 2 \text { bp, allowing the in-frame fusion with } \\
\text { gIII in an additional reading frame }\end{array}$ & This work \\
\hline pGEX $5 \times 2$ & $\begin{array}{l}\text { E. coli expression vector carrying an bla } \\
\text { resistance determinant, for construction of GST } \\
\text { fusion proteins }\end{array}$ & $\begin{array}{l}\text { GE Healthcare, } \\
\text { Munich, Germany }\end{array}$ \\
\hline pMSC0029-500 & $\begin{array}{l}\text { plasmid encoding the GST-MSC_0029 fusion } \\
\text { protein }\end{array}$ & This work \\
\hline pMSC0108-500 & $\begin{array}{l}\text { plasmid encoding the GST-MSC_0108 fusion } \\
\text { protein }\end{array}$ & This work \\
\hline pMSC0636-500 & $\begin{array}{l}\text { plasmid encoding the GST-MSC_0636 fusion } \\
\text { protein }\end{array}$ & This work \\
\hline
\end{tabular}


Table 1 - continued

\begin{tabular}{|c|c|c|}
\hline Primers & & \\
\hline MHLacZPro_f & $\begin{array}{l}\text { GGCTCGTATGTTGTGTGG; control for } \\
\text { phagemids; binds with LacZ promoter }\end{array}$ & Kügler et al., 2008 \\
\hline MHgIII_r1 & $\begin{array}{l}\text { CTAAAGTTTTGTCGTCTTTCC; control for } \\
\text { phagemids; binds with } p I I I\end{array}$ & Kügler et al., 2008 \\
\hline oMHORF3_Pme_rX1 & $\begin{array}{l}\text { CTTTGGATCCCTAATGATGATGGTGATGA } \\
\text { TG; primer for modification of pHORF3 by } \\
\text { adding } 1 \mathrm{bp}(\mathrm{pHORF} 3 \mathrm{X})\end{array}$ & This work \\
\hline $\begin{array}{l}\text { oMHORF3_Pme_ } \\
\text { rXX2 }\end{array}$ & $\begin{array}{l}\text { CTTTGGATCCCTAATGATGATGGTGATGA } \\
\text { TGG; primer for modification of pHORF3 by } \\
\text { adding } 2 \text { bp (pHORF3XX) }\end{array}$ & This work \\
\hline oMSC0029A & $\begin{array}{l}\text { GATCGAATTCAATGGGGACAACACACTCA } \\
\text { ATAT; forward primer to clone MSC_0029 }\end{array}$ & This work \\
\hline oMSC0029B & $\begin{array}{l}\text { CGATGCGGCCGCTTAAAAAGTTCTAGCAG } \\
\text { CTTCTAT; reverse primer to clone MSC_0029 }\end{array}$ & This work \\
\hline oMSC0108A & $\begin{array}{l}\text { ATAATCGAATTCAATGGATTTCAAGTGCT } \\
\text { TATTCAATTCAA; forward primer to clone } \\
\text { MSC_0108 }\end{array}$ & This work \\
\hline oMSC0108B & $\begin{array}{l}\text { TCCGATGCGGCCGCTCATCAATTAGTTTG; } \\
\text { reverse primer to clone MSC_0108 }\end{array}$ & This work \\
\hline oMSC0636A & $\begin{array}{l}\text { GACGAATTCAAATGGTTTATTATGCAAGA } \\
\text { AACAATGAACCG; forward primer to clone } \\
\text { MSC_0636 }\end{array}$ & This work \\
\hline oMSC0636B & $\begin{array}{l}\text { ATATGCGGCCGCTCATGATTTTAATTGTTC } \\
\text { TTTTAATTG; reverse primer to clone } \\
\text { MSC_0636 }\end{array}$ & This work \\
\hline \multicolumn{3}{|l|}{ Sera } \\
\hline Hyperimmune sera & $\begin{array}{l}\text { hyperimmune sera raised in rabbits against } \\
\text { different mycoplasmal species }\end{array}$ & FLI, Jena, Germany \\
\hline CBPP negative sera & preimmune sera obtained from uninfected cattle & ILRI Nairobi Kenya \\
\hline CBPP positive sera & $\begin{array}{l}\text { sera from CBPP infection trials, ILRI Nairobi, } \\
\text { Kenya }\end{array}$ & Jores et al., 2008 \\
\hline
\end{tabular}


Table 2

Immunogenic peptides identified in Mycoplasma mycoides subsp. mycoides small colony type (MmmSC)

\begin{tabular}{|c|c|c|c|c|c|c|}
\hline No & $\mathbf{F q}^{1)}$ & Genome position & Product from $\mathrm{MmmSC}$ & $\begin{array}{c}\text { Insert } \\
\text { length (bp) }\end{array}$ & Locus tag & OD\% ${ }^{2)}$ \\
\hline 1 & 3 & $733268-733109$ & Conserved hypothetical & 159 & MSC_0636 & $56.7 \%$ \\
\hline 2 & 2 & $127879-127937$ & Glycosyl transferase & 59 & MSC_0108 & $51.4 \%$ \\
\hline 3 & 7 & $696995-697122$ & ATP dependent protease & 128 & MSC_0613 & $43.7 \%$ \\
\hline 4 & 7 & $1153378-1153506$ & $\begin{array}{l}\text { DNA directed RNA } \\
\text { polymerase beta subunit }\end{array}$ & 199 & MSC_1009 & $39.5 \%$ \\
\hline 5 & 8 & $32410-32351$ & $\begin{array}{l}\text { Acyl carrier protein } \\
\text { phosphodiesterase }\end{array}$ & 60 & MSC_0029 & $37.3 \%$ \\
\hline 6 & 2 & $1205835-1205959$ & AAA family ATPase & 124 & MSC_1062 & $36.9 \%$ \\
\hline 7 & 6 & $1032859-1032922$ & Amino acid permease & ( & MSC_0908 & $34.3 \%$ \\
\hline 8 & 5 & $750456-750516$ & Conserved hypothetical & 60 & MSC_0656 & $32.7 \%$ \\
\hline 9 & 2 & $304438-304508$ & Pyruvate dehydrogenase & 71 & MSC_0266 & $30.0 \%$ \\
\hline 10 & 5 & $218668-218814$ & $\begin{array}{l}\text { Oligopeptide ABC trans- } \\
\text { porter, component OppA }\end{array}$ & 147 & MSC_0184 & $30.0 \%$ \\
\hline 11 & 8 & $159499-159643$ & $\begin{array}{c}\text { Hypothetical } \\
\text { transmembrane protein }\end{array}$ & 144 & MSC_0135 & $29.0 \%$ \\
\hline 12 & 4 & $1160317-1160401$ & $\begin{array}{l}\text { Glucose inhibited division } \\
\text { protein } \mathrm{A}\end{array}$ & 85 & MSC_1017 & $28.3 \%$ \\
\hline 13 & 2 & $23668-23767$ & $\begin{array}{l}\text { Mannitol-1-phosphate 5- } \\
\text { dehydrogenase }\end{array}$ & 99 & MSC_0017 & $26.8 \%$ \\
\hline 14 & 26 & $77529-77641$ & $\begin{array}{l}\text { Transcriptional regulator; } \\
\text { NifR3 family }\end{array}$ & 184 & MSC_0068 & $26.7 \%$ \\
\hline 15 & 3 & $940581-940693$ & Conserved hypothetical & 112 & MSC_0826 & $25.2 \%$ \\
\hline 16 & 19 & $1117031-1117172$ & UDP glucose 4-epimerase & 141 & MSC_0978 & $24.5 \%$ \\
\hline 17 & 5 & $44289-44393$ & D-Lactate dehydrogenase & 105 & MSC_0034 & $24.5 \%$ \\
\hline 18 & 4 & $701239-701317$ & Prolipoprotein & 78 & MSC_0617 & $23.8 \%$ \\
\hline 19 & 6 & $1210760-1210841$ & $\begin{array}{l}\text { Conserved hypothetical } \\
\text { transmembrane protein }\end{array}$ & 82 & MSC_1066 & $22.3 \%$ \\
\hline 20 & 4 & $698434-698492$ & $\begin{array}{c}\text { Putative hydrolase of } \\
\text { HAD family }\end{array}$ & 69 & MSC_0614 & $22.1 \%$ \\
\hline 21 & 3 & $385965-386234$ & $\begin{array}{l}\text { tRNA pseudoridine } \\
\text { syntase B }\end{array}$ & 269 & MSC_0336 & $21.0 \%$ \\
\hline 22 & 3 & $97781-98005$ & $\begin{array}{l}\text { Prolipoprotein ; putative } \\
\text { phosphate } A B C \text { transport }\end{array}$ & 224 & MSC_0079 & $21.0 \%$ \\
\hline
\end{tabular}

1) Frequency of clones among the random sample of 134 clones sequenced.

2) The optical density obtained with $\mathrm{MmmSC}$ whole cell lysate used as solid phase antigen served as positive control $(100 \%)$. 
Table 3

ELISA cross-reactivity of four clones with rabbit sera directed against 16 different Mycoplasma species

\begin{tabular}{|c|c|c|c|c|c|}
\hline \multirow[t]{2}{*}{ Serum raised aganist } & \multirow{2}{*}{$\begin{array}{l}\text { culture } \\
\text { collection } \\
\text { number }\end{array}$} & \multicolumn{4}{|c|}{ OD $\%+/$ - standard deviation } \\
\hline & & MSC_029 & MSC_0108 & MSC_636 & MSC_1062 \\
\hline A. axanthum $\mathrm{S} 743$ & NCTC 10138 & $28 \pm 8.6$ & $26 \pm 4.1$ & $35 \pm 2.3$ & $45 \pm 1.8$ \\
\hline A. laidlawii PG 8 & NCTC 10116 & $39 \pm 8.3$ & $43 \pm 0.2$ & $42 \pm 3.5$ & $39 \pm 1.7$ \\
\hline A. modicum $\mathrm{PG} 49$ & NCTC 10134 & $32 \pm 6.8$ & $26 \pm 0.6$ & $32 \pm 0.4$ & $51 \pm 1.2$ \\
\hline M. alkalescens PG 51 & ATCC 29103 & $17 \pm 0.6$ & $21 \pm 2.1$ & $43 \pm 1.3$ & $41 \pm 0.5$ \\
\hline M. arginini $\mathrm{G} 230$ & NCTC 10129 & $21 \pm 1.6$ & $21 \pm 0.3$ & $26 \pm 1.6$ & $32 \pm 0.3$ \\
\hline M. bovigenitalium PG 11 & ATCC 19852 & $17 \pm 0.3$ & $17 \pm 1.9$ & $22 \pm 1.1$ & $25 \pm 0.3$ \\
\hline M. bovirhinis PG 43 & NCTC 10118 & $36 \pm 4.8$ & $40 \pm 2.1$ & $44 \pm 14.9$ & $44 \pm 3.2$ \\
\hline M. bovis Donetta PG 45 & ATCC 25523 & $44 \pm 13.7$ & $39 \pm 2.5$ & $41 \pm 5.6$ & $49 \pm 2.3$ \\
\hline M. bovoculi M 165/69 & NCTC 10141 & $44 \pm 0.4$ & $42 \pm 8.8$ & $44 \pm 7.1$ & $33 \pm 2.9$ \\
\hline M. californicum ST-6 & ATCC 33461 & $21 \pm 2.5$ & $22 \pm 0.9$ & $32 \pm 0.6$ & $32 \pm 2.2$ \\
\hline $\begin{array}{l}\text { M. capricolum subsp. } \\
\text { capricolum california kid }\end{array}$ & NCTC 10154 & $45 \pm 21.7$ & $48 \pm 0.5$ & $45 \pm 1.4$ & $57 \pm 4.9$ \\
\hline M. gallinarum PG 16 & ATCC 19708 & $19 \pm 1.9$ & $28 \pm 2.4$ & $45 \pm 1.1$ & $44 \pm 0.3$ \\
\hline M. gatae C 8 & ATCC 23392 & $30 \pm 4.2$ & $21 \pm 4.0$ & $27 \pm 1.5$ & $31 \pm 2.0$ \\
\hline M. leachii PG 50 & NCTC 10133 & $46 \pm 6.0$ & $27 \pm 2.0$ & $33 \pm 4.3$ & $45 \pm 7.3$ \\
\hline $\begin{array}{l}\text { M. mycoides subsp. capri } \\
\text { y-goat }\end{array}$ & NCTC 10706 & $30 \pm 1.2$ & $27 \pm 2.3$ & $30 \pm 0.5$ & $34 \pm 3.4$ \\
\hline MmmSC PG 1 & NCTC 10114 & $100 \pm 4.6$ & $100 \pm 12.1$ & $100 \pm 2.5$ & $100 \pm 8.9$ \\
\hline Negative serum & - & $27 \pm 3.0$ & $30 \pm 2.6$ & $29 \pm 1.0$ & $36 \pm 0.7$ \\
\hline
\end{tabular}

